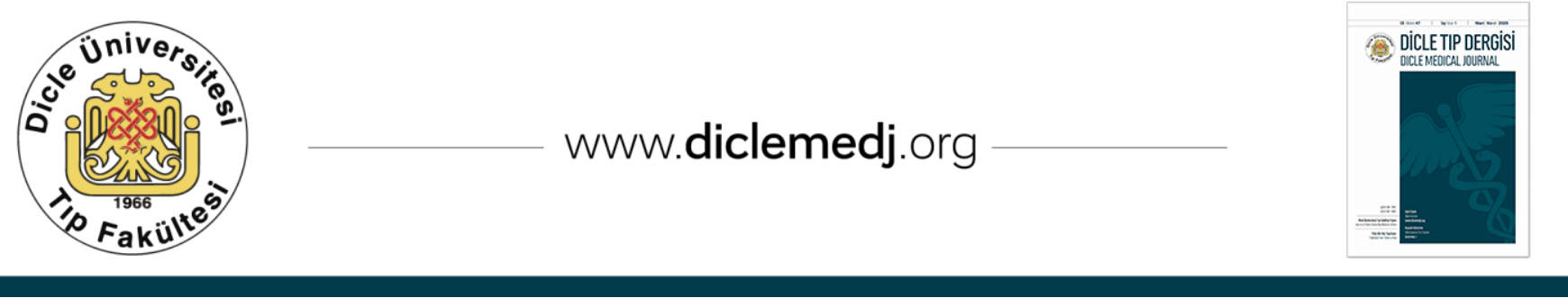

\title{
Value Of Cephalometric And Volumetric Measurements Performed By Multi-Level Three-Dimensional Computed Tomography In Patients With Obstructive Sleep Apnea Syndrome
}

\author{
Feride Fatma Görgülü1 ${ }^{\text {iD }}$, Sıdıka Deniz Yalım² \\ 1 Department of Radiology, University of Health Sciences, Adana Health Practice and Research Center, Adana, Turkey \\ 2 Specialist of Otorhinolaryngology, MD, Department of Otorhinolaryngology, University of Health Sciences, Adana Health Practice and Research Center, \\ Adana, Turkey
}

Received: 28.01.2020; Revised: 02.03.2020; Accepted: 03.03.2020

\begin{abstract}
Objective: Upper airway narrowing plays an important role in obstructive sleep apnea syndrome (OSAS) etiology. Computed tomography (CT) provides a three-dimensional image and can be obtained in the supine body position. The main objectives of this study were to determine the correlation between the dimensions of upper airway structures and OSAS by reconstructing the nasal, pharyngeal and oropharyngeal airway using CT.
\end{abstract}

Methods: The study was carried out on a total of 95 consecutive subjects with maxillofacial CT, including 59 OSAS patients and 36 healthy participants. CT data of the study subjects were obtained in the supine position with the Philips Ingeniuty Core 2017 model CT device. Volumetric and cross-sectional area measurements of upper airway were obtained in three dimensions.

Results: Retrolingual area and retrouvulal area were significantly lower in the patient group ( $<<0.001$ for two). The mean values of soft palate volume, tongue volume and concha volumes of both sides were found to be significantly higher in the patient group ( $p=0.005$ for lower right turbinate, $p<0.001$ for others). Total nasal passage volume averages were significantly lower in the patient group, however naso-pharyngeal volume averages were significantly lower in the control group ( $p<0,001, p=0,004$ respectively). Both uvula thickness and soft palate length averages were significantly higher in the patient group ( $\mathrm{p}<0.001$ for both).

Conclusion: Cephalometric analysis of patients with OSAS with CT scans provides objective evaluation of skeletal and soft tissue abnormalities. We believe that all surgical procedures should follow precise cephalometric measurements, including detailed measurements.

Keywords: Obstructive sleep apnea syndrome, maxillofacial CT, upper airway cephalometry 


\section{Tıkayıcı Uyku Apne Sendromlu Hastalarında Multi-Level Üç Boyutlu Bilgisayarlı Tomografi İle Yapılan Sefalometrik Ve Volumetric Ölçümlerin Değeri}

Öz

Amaç: Üst solunum yolu daralması, tıkayıcı uyku apne sendromu (TUAS) etiyolojisinde önemli bir rol oynar. Bilgisayarlı tomografi (BT) üç boyutlu bir görüntü sağladığı gibi sırtüstü vücut pozisyonunda çekilebilir. Bu çalışmanın amacı temel hedefi, nazal, faringeal ve orofaringeal hava yolu rekonstrüksiyonu yaparak, TUAS ile üst hava yolu yapılarının boyutları arasındaki korelasyonu ortaya koymaktı.

Yöntemler: Çalışma, 59 TUAS hastası ve 36 sağlıklı katılımcı dahil olmak üzere maksillofasiyal BT'li toplam 95 hasta üzerinde gerçekleştirildi. Çalışma deneklerinin BT verileri sırtüstü pozisyonda Philips Ingeniuty Core 2017 model BT cihazı ile elde edildi. Üst hava yolunun volumetric ve kesitsel alanı ölçümleri üç boyutta ölçüldü.

Bulgular: Retrouvulal alan ve retrolingual alan hasta grubunda anlamlı olarak daha düşüktü (iki hasta için $\mathrm{p}<0.001$ ). Her iki tarafın konka hacimlerinin, yumuşak damak hacminin ve dil hacmi değerleri hasta grubunda anlamlı olarak daha yüksek bulundu (sağ alt konka için $\mathrm{p}=0.005$, diğerleri için $\mathrm{p}<0.001$ ). Toplam nazal pasaj hacmi hasta grubunda anlamlı olarak düşükken, nazo-faringeal hacim kontrol grubunda anlamlı olarak düşük bulundu (sırasıyla $p<0,001, p=0,004$ ). Uvula kalınlığı ve yumuşak damak uzunluğu hasta grubunda anlamlı olarak daha yüksekti (her ikisi için $\mathrm{p}<0.001$ ).

Sonuç: BT, TUASlı hastaların sefalometrik analizi, iskelet ve yumuşak doku anormalliklerinin objektif değerlendirilmesini sağlar. Tüm TUAS cerrahi prosedürlerinin ayrıntılı ölçümlerin de dahil edildiği sefalometrik ölçümler sonrası yapılması gerektiğine inanıyoruz.

Anahtar kelimeler: Tıkayıcı uyku apne sendromu, maksillofasiyal BT, üst solunum yolu sefalometrisi.

\section{INTRODUCTION}

Obstructive sleep apnea syndrome (OSAS) is a sleep-related anatomical and functional respiratory disorder characterized by repeated airway narrowing or even upper airway collapse during sleep. This process is ultimately leads to recurrent oxygen desaturation and sleep division. The diagnosis of OSAS is made by polysomnography with the use of apneahypopnea index (AHI) $\geq 5$ / hour with the presence of symptoms, or use of AHI $\geq 15$ / hour without symptoms ${ }^{1,2}$. The pathophysiology of airway narrowing in OSAS is theoretically possible with sleeping in the supine position, high BMI, excessive neck fat, gravity effects, adenoid and tonsillar hypertrophy, macroglossia, pharyngeal muscle fluxity, base of tongue proptosis, craniofacial abnormalities, enlarged uvula and inferior positioning of the hyoid. A better understanding of structural changes in the upper airway would help predicting pathophysiology of OSAS and treatment planning 3,4 . This process finally results in decreased blood oxygen levels, sleep division, increased upper respiratory resistance, symptoms from snoring alone to obstructive sleep apnea, pulmonary and cardiovascular events and daytime hypersomnia that causing behavioral changes and occupational disability $2,4,5$.

Radiological methods are very helpful for the upper airway evaluation of OSAS patients and can be used for comparative cephalometric and volumetric analysis before and after surgical treatment ${ }^{6,7}$. Since recurrent collapse of the upper airway during sleep is one of the most important pathogenesis in OSAS, endoscopic or radiological imaging methods such as cephalometry, computed tomography (CT), magnetic resonance imaging (MRI) etc. have 
aimed to detect the narrowed portion of the upper airway ${ }^{8,9}$. Most radiological studies have examined only the anterior-posterior width and minimal cross-sectional area in the transverse plane at different levels of the upper airway ${ }^{10,11}$. However, the three-dimensional (3-D) examination of the upper airway passage as a whole with neighboring tissues from the nasal tip to the hypopharynx can more easily capture the targeted narrow area and reveal where the surgeon should focus.

Morphologic and functional differences of upper respiratory tract have been reported between the normal population and OSAS patients, as well as the sleep and wake periods of OSAS patients ${ }^{2,12,13}$. CT provides a 3-D image and can be achieved in the supine body position which is important because of changes in body posture that affect the size of the upper airways during respiration. This technique can provide images throughout the entire respiratory cycle ${ }^{8}$. However, radiocephalometry can only provide a two-dimensional representation and the chances of giving information about soft tissues or cavities are limited. A variety of 3-D imaging techniques have been developed, including CT, conebeam CT, and MRI ${ }^{9,14}$.

The main objectives of this study were to determine the correlation between the anatomical skeletal, soft tissue dimensions of upper airway structures and obstruction in adult sleep apnea compared to control subjects and to investigate structural changes in the upper airway passages that were created by upper airway volume and adjacent anatomical structures by reconstructing the nasal, pharyngeal and oropharyngeal airway using 3D multi-detector CT.

\section{METHODS}

This study was carried out in the Otorhinolaryngology clinic of Adana Health Practice and Research Center of University of Health Sciences with the approval of the ethics committee of our hospital and with informed consent from the patients and following the Declaration of Helsinki principles.

In our study, 59 patients with maxillofacial CT from OSAS patients admitted to the sleep center of our hospital were included in the study. Patient and control group data were obtained from the digital archive of the our hospital. Age, sex and cephalometric and volumetric measurements of patients' nasal cavity, nasopharynx and oropharynx were recorded in the study forms. Exclusion criteria in the patient group were being under 18 years of age, presence of severe maxillofacial malformation, having nasal polyposis and chronic sinusitis, presence of adenoid tissue, abnormal mass lesion obstructing airway passage from nasal tip to hypopharynx, having previously had any nasal, nasopharyngeal and oropharyngeal surgery received. The control group consisted of 36 patients with maxillofacial CT applied to the otorhinolaryngology outpatient clinic for various reasons. Exclusion criteria in the control group were being younger than 18 years of age and having any nasal pathology such as nasal polyps, sinusitis, presence of abnormal mass lesion occluding upper airway passage and presence of nasopharyngeal pathology such as adenoid.

CT data of the study subjects in both groups were obtained in the supine position with a section thickness of $0.67 \mathrm{~mm}$ with the Philips Ingeniuty Core 2017 model CT device with multislice 128 section multidetector. Threedimensional volumetric analysis was performed on the workstation with Philips Intellispace Portal program. To avoid motion errors, patients were instructed to hold their breath at the end of the scan. Inferior turbinate volumes (Figure 1), total nasal passage volume (Figure 2), nasopharyngeal volume and oropharyngeal volume (Figure 3), soft palate and tongue volume (Figure 4), soft palate length and uvula thickness (Figure 5), retrouvulal and 
retrolingual cross-sectional area measurements (Figure 6) were measured in three dimensions by FFG. FFG had eighteen years' radiology experience and was blind to data regarding OSAS status of the individuals and recorded data in $\mathrm{mm} 2$, cc and $\mathrm{mm}$.

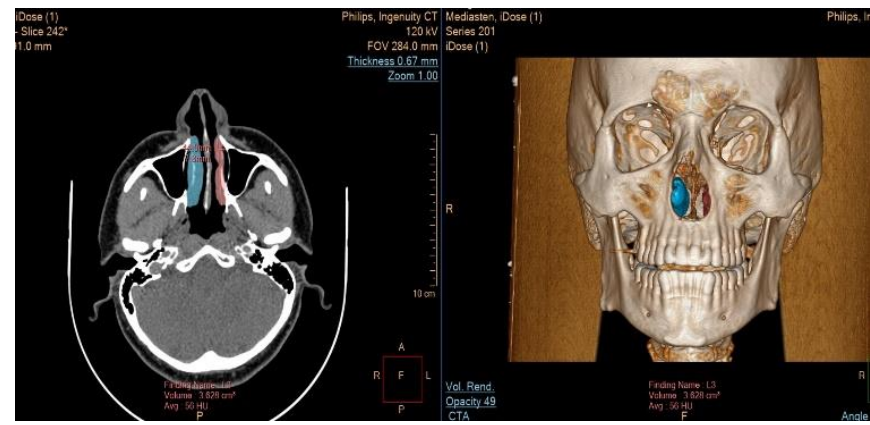

Figure 1: Inferior turbinate volumetric analysis (right blue, left pink color)

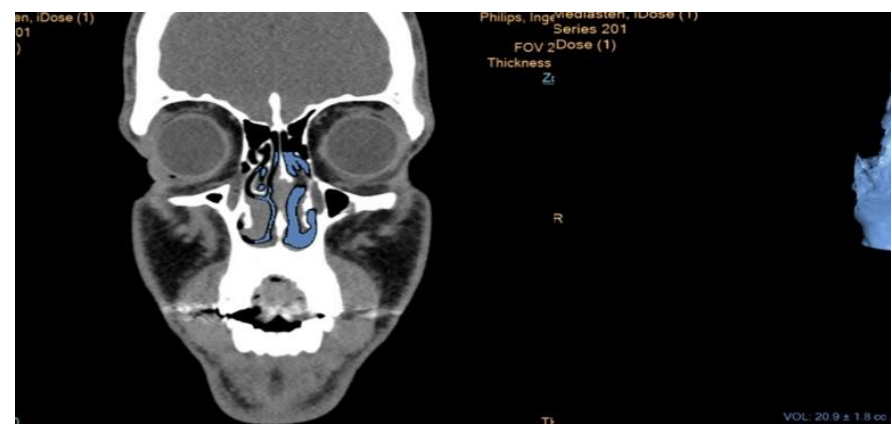

Figure 2: Image of total nasal passage volume (extracted image at the right, CT at the left)

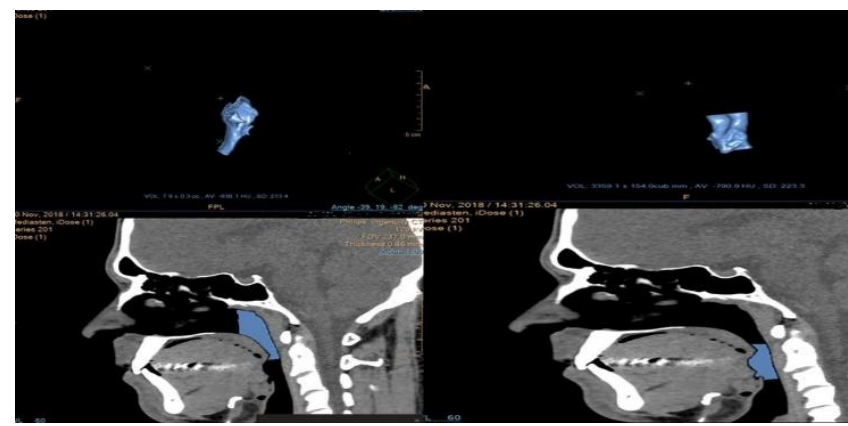

Figure 3: Extracted and CT image of nasopharyngeal (left) and oropharyngeal volume(right)

Turbinate, soft palate and tongue volumes analysis were done by the help of tumor tracking methods. Then, measurements made in patient and control groups were compared and analyzed for statistically significant differences. Logistic regression was used to calculate how much of the variables were converted into clinical risk. In logistic regression analysis, patient and control groups were used as dependent variables
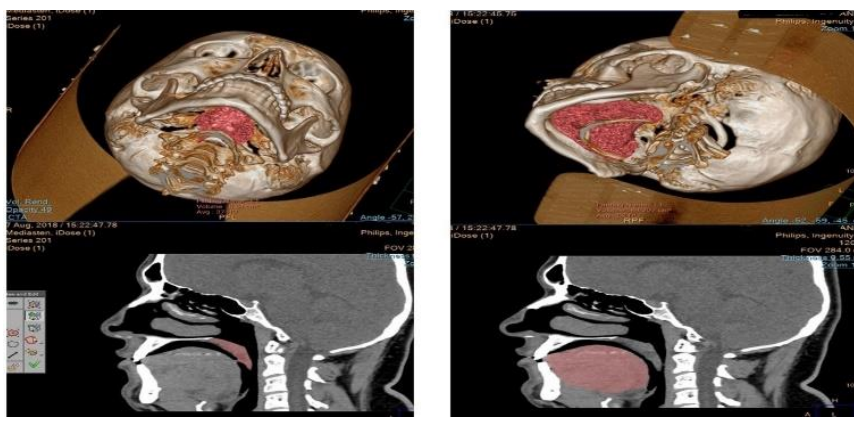

Figure 4: Soft palate (left) and tongue (right) volume analysis in tumor tracking method

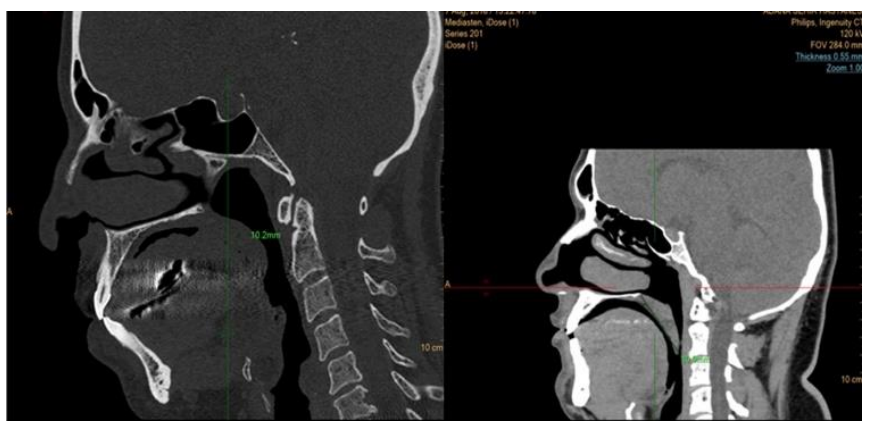

Figure 5: Soft palate length (right)and uvula thickness (left) measurements
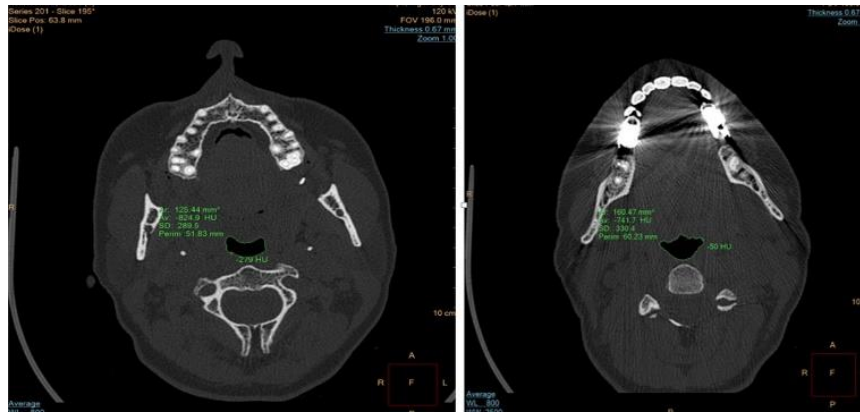

Figure 6: Retrouvulal (left) and retrolingual (right) crosssectional area measurement

\section{Statistical Analysis}

The variables were divided into two categories as categorical and continuous. Categorical data were shown as numbers and percentages and compared with chi-square. Shapiro-Wilk test was used to check whether the data were compatible with normal distribution. The difference between the mean of the patient and control groups was calculated with Student's t test. 
The mean, standard deviation, minima and maxima were used as the descriptive statistics. Odds ratios were used and 95\% confidence intervals applied in univariate and multivariate analyses. The SPSS Statistics 21.0 (SPSS Inc., Chicago, IL, United States) package application was used to perform all the statistical calculations reported here In all cases, statistical signifi $\neg$ cance was defined as a $\mathrm{p}$ value less than 0.05 .

\section{RESULTS}

There was no significant difference between the patient and control groups in terms of mean age and $\operatorname{sex}(\mathrm{p}=0.134, \mathrm{p}=0.438$, respectively) (Table I).

Table I: Age and gender distrubition between OSAS and control groups

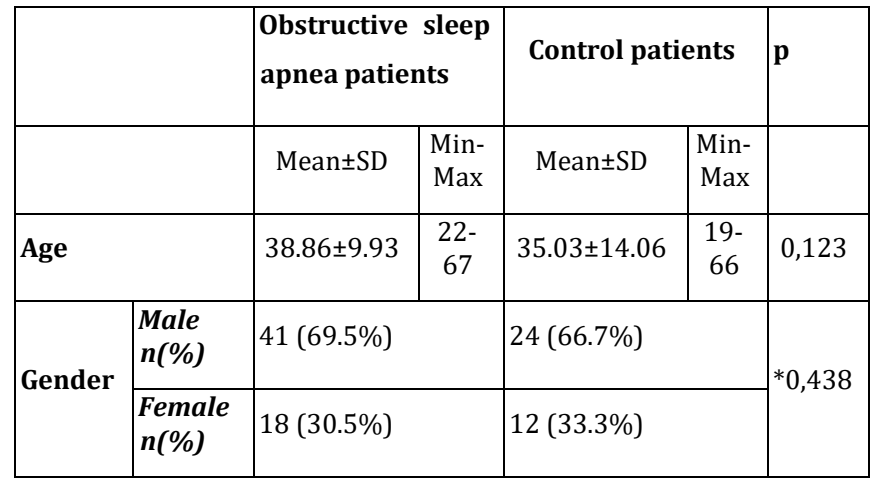

p: Student's t Test, *Ki-Square Test

In the cross-sectional analysis, retrouvulal area and retrolingual area were significantly lower in the patient group ( $\mathrm{p}<0.001$ for two) (Table II). When the volumetric analysis of the structures that are likely to narrow the passage was evaluated, the mean values of right inferior concha volume, left inferior concha volume, soft palate volume and tongue volume were found to be significantly higher in the patient group. ( $p=0.005$ for lower right turbinate, $p<0.001$ for others) (Table II). Total nasal passage volume averages were significantly lower in the patient group and naso-pharyngeal volume averages were significantly lower in the control group ( $p<0,001, p=0,004)$ (Table II). Both soft palate length and uvula thickness averages were significantly higher in the patient group $(\mathrm{p}<0.001$ for both) (Table II).
Table II: Cross-sectional and volumetric comparison of multilevel cephalometric values obtained by craniofacial CT data analysis between OSAS and control groups

\begin{tabular}{|l|c|c|c|c|c|}
\hline & \multicolumn{2}{|c|}{$\begin{array}{c}\text { Obstructive sleep } \\
\text { apnea patients }\end{array}$} & \multicolumn{3}{c|}{ Control subjects } \\
\hline & Mean \pm SD & Min-Max & Mean \pm SD & Min-Max & p \\
\hline NASAL CAVITY MEASUREMENTS & & & & \\
\hline $\begin{array}{l}\text { Right } \\
\text { inferior } \\
\text { concha } \\
\text { volume, cc }\end{array}$ & $5.57 \pm 2.14$ & $1.37-9.97$ & $4.34 \pm 1.77$ & $1.93-8.83$ & $\mathbf{0 , 0 0 5}$ \\
\hline $\begin{array}{l}\text { Left inferior } \\
\text { concha } \\
\text { volume, cc }\end{array}$ & $5.12 \pm 2.04$ & $0.97-9.4$ & $3.90 \pm 1.07$ & $2.47-7.00$ & $<\mathbf{0 , 0 0 1}$ \\
\hline $\begin{array}{l}\text { Total nasal } \\
\text { passage } \\
\text { volume, cc }\end{array}$ & $18.42 \pm 7.57$ & $\begin{array}{c}5.60- \\
43.90\end{array}$ & $25.29 \pm 5.81$ & $\begin{array}{c}11.10- \\
34.90\end{array}$ & $<\mathbf{0 , 0 0 1}$ \\
\hline
\end{tabular}

\begin{tabular}{|c|c|c|c|c|c|}
\hline \multicolumn{6}{|c|}{ NASO-PHARYNX REGION MEASUREMENTS } \\
\hline $\begin{array}{l}\text { Naso- } \\
\text { pharyngeal } \\
\text { volume, cc }\end{array}$ & $8.96 \pm 2.86$ & $3.34-16.4$ & $7.18 \pm 2.77$ & $3.33-14.7$ & 0,004 \\
\hline $\begin{array}{l}\text { Soft palate } \\
\text { length, } \mathrm{mm}\end{array}$ & $38.72 \pm 5.77$ & $24.5-48.5$ & $29.71 \pm 5.39$ & $22.2-48.5$ & $<0,001$ \\
\hline $\begin{array}{l}\text { Uvula } \\
\text { thickness, } \\
\text { mm }\end{array}$ & $9.47 \pm 2.01$ & $6.5-14.1$ & $7.06 \pm 0.69$ & $6.1-10$ & $<0,001$ \\
\hline $\begin{array}{l}\text { Soft palate } \\
\text { volume, cc }\end{array}$ & $8.44 \pm 2.83$ & $3.33-14.9$ & $3.05 \pm 1$ & $1.87-6.88$ & $<0,001$ \\
\hline $\begin{array}{l}\text { Retro- } \\
\text { uvulal area, } \\
\mathrm{mm}^{2}\end{array}$ & $124.76 \pm 59.01$ & $\begin{array}{l}31.71- \\
282.45\end{array}$ & $178.96 \pm 64.65$ & $\begin{array}{c}85.3- \\
342.92\end{array}$ & $<0,001$ \\
\hline \multicolumn{6}{|c|}{ ORAL CAVITY and OROPHARYNGEAL MEASUREMENTS } \\
\hline $\begin{array}{l}\text { Oro- } \\
\text { pharyngeal } \\
\text { volume, cc }\end{array}$ & $7.83 \pm 2.53$ & $3.4-14$ & $6.96 \pm 2.36$ & $3.23-12.3$ & 0,098 \\
\hline $\begin{array}{l}\text { Tongue } \\
\text { volume, cc }\end{array}$ & $89.33 \pm 13.92$ & $49-122.23$ & $62.87 \pm 9.67$ & $\begin{array}{l}52.34- \\
88.87\end{array}$ & $<0,001$ \\
\hline $\begin{array}{l}\text { Retrolingual } \\
\text { area, } \mathrm{mm}^{2}\end{array}$ & $208.54 \pm 82.57$ & $\begin{array}{l}54.98- \\
461.05\end{array}$ & $265.77 \pm 89.66$ & $\begin{array}{l}119,72- \\
412.66\end{array}$ & 0,002 \\
\hline
\end{tabular}

p:Student's $t$ Test

When univariete analysis of parameters was performed, right inferior concha, left inferior concha, naso-pharyngeal volume, soft palate length, especially uvula thickness and soft palate volume heights were found to be related with OSAS. In addition, the decrease in total nasal passage volume, retro-uvulal area and retrolingual area measurements were found to be associated with OSAS (Table III). 
Table III: Univarite analysis of study parameters

\begin{tabular}{|c|c|c|c|}
\hline & \multicolumn{3}{|c|}{ Univariate Analysis } \\
\hline & OR & $95 \% \mathrm{CI}$ & $\mathrm{p}$ \\
\hline \multicolumn{4}{|c|}{ NASAL CAVITY MEASUREMENTS } \\
\hline $\begin{array}{l}\text { Right inferior concha } \\
\text { volume }\end{array}$ & 1.380 & $1.093-1.741$ & 0.007 \\
\hline $\begin{array}{l}\text { Left inferior concha } \\
\text { volume }\end{array}$ & 1.522 & $1.159-1.999$ & 0.003 \\
\hline $\begin{array}{l}\text { Total nasal passage } \\
\text { volume }\end{array}$ & 0.869 & $0.810-0.933$ & $<0.001$ \\
\hline \multicolumn{4}{|c|}{ NASO-PHARYNX REGION MEASUREMENTS } \\
\hline $\begin{array}{l}\text { Naso-pharyngeal } \\
\text { volume }\end{array}$ & 1.270 & $1.071-1.507$ & 0.006 \\
\hline Soft palate length & 1.300 & $1.174-1.441$ & $<0.001$ \\
\hline Uvula thickness & 5.290 & $2.519-11.110$ & $<0.001$ \\
\hline Soft palate volume & 4.916 & $2.428-9.956$ & $<0.001$ \\
\hline Retro-uvulal area & 0.986 & $0.979-0.994$ & $<0.001$ \\
\hline \multicolumn{4}{|c|}{ ORAL CAVITY and OROPHARYNGEAL MEASUREMENTS } \\
\hline Tongue volume & 1.175 & $1.104-1.250$ & $<0.001$ \\
\hline Retrolingual area & 0.992 & $0.987-0.997$ & $<0.001$ \\
\hline
\end{tabular}

When all parameters were evaluated together, it was seen that naso-pharyngeal volume and soft palate volume excess and retro-uvulal area stenosis were prominent in the patient group compared to the control group (Table IV).

Table IV: Multivariate analysis of all variables

\begin{tabular}{|l|c|c|c|}
\hline & OR & $95 \%$ CI & $p$ \\
\hline Naso-pharyngeal volume & 2.249 & $1.139-4.44$ & 0.019 \\
\hline Soft palate volume & 7.051 & $2.03-24.495$ & 0.002 \\
\hline Retro-uvulal area & 0.950 & $0.918-0.983$ & 0.003 \\
\hline
\end{tabular}

p:Logistic Regression

\section{DISCUSSION}

In present study, we demonstrated that OSAS is associated with significant differences compared to control group in certain cephalometric measurements. In the volumetric analysis of the upper airway and adjacent anatomical structures, the mean values of volumes of right inferior concha, left inferior concha, soft palate and tongue were found to be statistically higher and significant in the patient group. Total nasal passage volume averages were significantly lower in the patient group and naso-pharyngeal volume averages were significantly lower in the control group.

The upper airway passage is surrounded by soft tissues such as concha, tongue, velopharynx and lateral pharyngeal wall, which are surrounded by protective bone structures. Pharyngeal airway size during sleep is thought to be determined by anatomical balance between the volume of three-dimensional soft tissue and the size of the surrounding bone structure ${ }^{15}$. Some anatomical factors may contribute to position dependence in OSAS patients. The cephalometric parameters of some craniofacial skeletal and soft tissue structures of OSAS patients differ from those of non-apneic control patients $8,13,16$. When performing a physical examination for OSAS, the clinician should elaborate upper airway examination and pay particular attention to obesity, thick and short neck, receding chin, craniofacial deformities, adenotonsillar hypertrophy, nasal septum deviation, concha hypertrophy, crowded oropharynx and a bulky tongue $2,4,17$. For example, the presence of OSAS will increase in patients with high body mass index and thick neck circumference ${ }^{17}$.

A three-dimensional CT study to investigate changes in the upper airway that developed over time showed that upper airway length and volume increased to about 20 years old, plateaued up to 50 years old, and then decreased rapidly ${ }^{18}$.

Minimal posterior airway cavity at the base of the tongue due to posterior pharyngeal wall thickening is associated with the severity of sleep apnea ${ }^{19}$. The position-dependent sleep problem in OSAS is defined as a condition in patients who have the apnea hypopnea index (AHI) at the lateral sleep is one half or less than the supine position ${ }^{15}$. During wakefulness, CT 
may not predict the development of airway occlusion at the lower level of the soft palate. It is impractical to evaluate the collapse region with measurements taken while awake ${ }^{18}$. Ciscar et al. 20 emphasize that changes in airway narrowing during sleep are greater.

CT is used for upper airway passage assessments in OSAS patients as it is sensitive to the detection of both bone and soft tissue bookmarks and provides dimensional information in near-real-time imaging ${ }^{9,21}$. CT measurements are usually performed in the supine position. This position during shooting, seems to be important because it changes posture and muscle tone and airway dimensions. In the supine position, the tongue and soft palate tend to fall backwards, and the already reduced air passage shows further narrowing with this effect ${ }^{22}$. CT evaluations have several advantages, such as more accurate measurements, three-dimensional imaging, supine body position, and image acquisition throughout the respiratory cycle. As the pharyngeal lumen is continuously fluctuating with respiratory phases and operatordependent bias may also affect measurements, measurements with different software programs allow for more accurate measurement. However, it is ideal to perform a CT measurement while the patient is asleep. Dental amalgam artifacts and beam-hardening artifacts of dense mandible are disadvantages of CT. But these do not cause the global image disruption ${ }^{9}$.

While OSAS patients have a circular or less elliptic shaped pharynx shape caused by a transverse axis reduction, a longer transverse axis elliptical pharynx shape has been observed in healthy individuals ${ }^{23,24}$. In another study, it was found that the soft palate length was significantly higher in OSAS patients compared to the control group, and the pharyngeal airway was significantly reduced in both the nasopharyngeal and velopharyngeal levels, as well as the anterior-posterior dimensions at the hypopharyngeal level. In our study, both soft palate length and uvula thickness values were significantly higher in the patient group. Changes and collapsibility of the velopharynx diameter during the respiratory cycle were higher in apnea patients, especially during sleep, than in normal subjects ${ }^{25}$. Propofolsedated children have been shown to have higher upper airway volumes in the lateral lying position than the supine position ${ }^{26}$. The crosssectional area of retrouvulal and retrolingual region were also significantly lower in the patient group in the present study.

In our study, the tongue volumes of patients with OSAS were significantly higher than those of the control group. In another study, tongue volume was found to be the strongest clinical predictor of OSA among anatomic measurements ${ }^{27}$.

Two studies investigated the importance of UAL (upper airway length). First one explained that the UAL was significantly longer in men than in women. In the second study, similar results were obtained, but in the severe OSAS group, UAL was significantly longer than in the control group or mild / moderate OSAS group 7,28 .

The correlation between narrowing in the upper airway and collapsibility can be explained by the Bernoulli principle, indicating that increased air velocity produces low pressure due to non-viscous fluid ${ }^{29}$. Since the velocity of the air passing through the narrowed intraluminal cavity of the upper airway also increases, subsequent reduced intraluminal pressure may jeopardize the patency of the upper airway during inhalation ${ }^{28}$.

In many publications, the upper airway has been scanned in the transverse plane to determine the narrowed region in OSAS patients 28,30 . However, the correlation between focusing on the transverse plane and the severity of OSAS may be inconsistent. For 
example, Bhattacharyya et al. ${ }^{9}$ evaluated the upper airways using 3-D CT and found no significant difference in upper airways size between OSAS and control patients.

Our study had some limitations. First, the CT study was performed with the patient awake, which might affect muscle tone rather than those who were asleep under sedation or anesthesia. Second, this study includes the small sample size of both the control and OSAS group. As the third, we performed this morphological study without classifying OSAS patients as mild, moderate and severe. In addition, it was not considered whether patients included in the study used CPAP therapy or not. In order to overcome these limitations, more detailed study of these anatomical variables is needed.

\section{CONCLUSIONS}

Statistically significant changes in cephalometric measurements were observed in the patients with OSAS. Cephalometric analysis with CT scans provides objective evaluation of skeletal and soft tissue abnormalities. It also allows us to better decide which surgery will be used to treat the patient. We think that preoperative evaluation of OSAS patients will contribute to the treatment especially with maxillofacial CT scans with easier and more accurate measurements applied to soft tissues more effectively. It would be promising to perform cephalometric analysis in OSAS patients in larger study groups and to evaluate the effectiveness of surgical procedures. We believe that all surgical procedures should follow precise cephalometric measurements, including detailed measurements.

Ethics Committee Approval: This study was carried out in the Otorhinolaryngology clinic of Adana Health Practice and Research Center of University of Health Sciences with the approval of the ethics committee of our hospital (21.11.2018/317) and with informed consent from the patients and following the Declaration of Helsinki principles.

Conflicts of interest: The authors have no conflict of interests to declare.

Financial Disclosure: The authors declared that this study has received no financial support.

\section{REFERENCES}

1. Ayas NT, Drager LF, Morrell MJ, Polotsky VY. Update in sleep-disordered breathing 2016. Am J Respir Crit Care Med. 2017; 195: 1561-6.

2. Atılgan ZA, Abakay A, Ülgen S. Obstructive sleep apnea syndrome and cardiovascular problems. Dicle Med J. 2011; 38: 253-6.

3. Epstein LJ, Kristo D, Strollo PJ Jr, et al. Clinical guideline for the evaluation, management and long-term care of obstructive sleep apnea in adults. J Clin Sleep Med. 2009; 5: 263-76.

4. Öncel GZ, Hüseyinoğlu N, Özlece HK. Analysis of vitamin D Receptor Polymorphisms in Turkish Patients with Obstructive Sleep Apnea Syndrome. Dicle Med J. 2019; 46: 771-80.

5. Patel JA, Ray BJ, Fernandez-Salvador C, Gouveia C, Zaghi S, Camacho M. Neuromuscular function of the soft palate and uvula in snoring and obstructive sleep apnea: a systematic review. Am J Otolaryngol. 2018; 39: 327-37.

6. Butterfield KJ, Marks PL, McLean L, Newton J. Linear and volumetric airway changes after maxillomandibular advancement for obstructive sleep apnea. J Oral Maxillofac Surg. 2015; 73: 1133- 42.

7. Hsieh YJ, Liao YF, Chen NH, Chen YR. Changes in the calibre of the upper airway and the surrounding structures after maxillomandibular advancement for obstructive sleep apnoea. Br J Oral Maxillofac Surg. 2014; 52: 445-51.

8. Ryu $\mathrm{HH}$, Kim $\mathrm{CH}$, Cheon SM, et al. The usefulness of cephalometric measurement as a diagnostic tool for obstructive sleep apnea 
syndrome: a retrospective study. Oral Surg Oral Med Oral Pathol Oral Radiol. 2015; 119: 20-31.

9. Bhattacharyya N, Blake SP, Fried MP. Assessment of the airway in obstructive sleep apnea syndrome with 3-dimensional airway computed tomography. Otolaryngol Head Neck Surg. 2000; 123: 444-9.

10. Weaver TE, Calik MW, Farabi SS, et al. Innovative treatments for adults with obstructive sleep apnea. Nat Sci Sleep. 2014; 6: 137-47.

11. Ogawa T, Enciso R, Shintaku WH, Clark GT. Evaluation of crosssection airway configuration of obstructive sleep apnea. Oral Surg Oral Med Oral Pathol Oral Radiol Endod. 2007; 103: 1028.

12. Wang YL, Mcdonald JP, Liu YH, et al. Analysis of the dynamic changes in the soft palate and uvula in obstructive sleep apnea-hypopnea using ultrafast magnetic resonance imaging. Genet Mol Res. 2014; 13: 8596-8608.

13. Castellani C, Francia G, Dalle Carbonare L, et al. Morphological study of upper airways and long-term follow-up of obstructive sleep apnea syndrome in acromegalic patients. Endocrine. 2016; 5: 308-16.

14. Swennen GR, Schutyser F, Barth EL, De Groeve P, De Mey A. A new method of 3-D cephalometry Part I: the anatomic Cartesian 3D reference system. J Craniofac Surg. 2006; 17: 314-25.

15. Tsuiki S, Isono $S$, Ishikawa T, Yamashiro $Y$, Tatsumi K, Nishino T. Anatomical balance of the upper airway and obstructive sleep apnea. Anesthesiology. 2008; 108: 1009-15.

16. Araz O, Turan A, Yoruk O, Alper F, Akgun M. Laryngocele and epiglottic cyst as rare causes of obstructive sleep apnea. Sleep Breath. 2009; 13: 285-7.

17. Wong SH, Ng BY. Review of sleep studies of patients with chronic insomnia at a sleep disorder unit. Singapore Med J. 2015; 56: 31723.

18. Schendel SA, Jacobson R, Khalessi S. Airway growth and development: a computerized 3dimensional analysis. J Oral Maxillofac Surg. 2012; 70: 2174-83.

19. Li KK, Powell NB, Kushida C, Riley RW, Adornato B, Guilleminault C. A comparison of asian and white patients with obstructive sleep apnea syndrome. Laryngoscope. 1999; 109: 1937-40.

20. Ciscar MA, Juan G, Martinez V, et al. Magnetic resonance imaging of the pharynx in OSA patients and healthy subjects. Eur Respir J. 2001; 17: 79-86.

21. Günbahar H, Ekin S, Sünnetçioğlu A, et al. The relationship between neutrophil-tolymphocyte ratio and platelet-to-lymphocyte ratio in patients with obstructive sleep apnea syndrome. Dicle Med J. 2015; 42: 289-93.

22. Battagel JM. Obstructive sleep apnoea: fact not fiction. Br J Orthod. 1996; 23: 315-24.

23. Rodenstein DO, Dooms G, Thomas Y, et al. Pharyngeal shape and dimensions in healthy subjects, snorers, and patients with obstructive sleep apnoea. Thorax. 1999; 45: 722-27.

24. Chau KW, Ng DK, Kwok CK, Chow PY, Ho JC. Clinical risk factors for obstructive sleep apnoea in children. Singapore Med J. 2003; 44: 570-3.

25. Suto Y, Matsuda E, Inoue Y. MRI of the pharynx in young patients with sleep disordered breathing. Br J Radiol. 1996; 69: 1000-4.

26. Litman RS, Wake N, Chan LM, et al. Effect of lateral positioning on upper airway size and morphology in sedated children. Anesthesiology. 2005; 103: 484-8.

27. Barrera JE, Pau CY, Forest VI, Holbrook AB, Popelka GR. Anatomic measures of upper airway structures in obstructive sleep apnea. 
World J Otorhinolaryngol Head Neck Surg. 2017; 3: 85-91.

28. Kim EJ, Choi JH, Kim YS, et al. Upper airway changes in severe obstructive sleep apnea: upper airway length and volumetric analyses using 3D MDCT. Acta Otolaryngol. 2011; 131: 527-32.
29. Fajdiga I. Snoring imaging: could Bernoulli explain it all? Chest. 2005; 128: 896-901.

30. Yucel A, Unlu M, Haktanir A, Acar M, Fidan F. Evaluation of the upper airway cross-sectional area changes in different degrees of severity of obstructive sleep apnea syndrome: cephalometric and dynamic CT study. AJNR Am J Neuroradiol. 2005; 26: 2624-9. 